\title{
Patients' Perceptions in Inpatient Service Quality and its Effect on Patient Loyalty with Patient Satisfaction as Mediation Variable
}

\author{
Octa Lidya Ghaisani Amin ${ }^{*}$ Wisnu Untoro \\ Faculty of Economics and Business, Universitas Sebelas Maret, Indonesia
}

\begin{abstract}
This study aims to empirically test the patient's perception of the quality of inpatient services, and its effects on the loyalty of the patient, with patient satisfaction as a mediation variable. Data collection was performed by using five points Likert scales with judgment sampling approach. The study involved 160 patients of the dr. Prijonegoro Hospital, Sragen. Descriptive analysis was conducted followed by measurement analyses to ensure the validity and reliability. This research found that inpatient service quality has a significant positive effect on patients' satisfaction, patient satisfaction positively affect patients' loyalty, and patients' satisfaction partially mediated the effect of inpatient service quality on patient loyalty. Therefore, by improving the quality of services, it is expected that the patients were satisfied and then loyal after satisfied with inpatient service quality in the hospital.
\end{abstract}

Keywords: inpatient service quality, patient satisfaction, patient loyalty

\section{Introduction}

Development of service quality standards indeed become an important thing to be noted that a company can survive. With increasing competition in the field of services, particularly hospitals, it is necessary to pay attention to all aspects of the quality of service contained therein. Quality of service and patient satisfaction is a key metric used by health care providers in an effort of continuous process improvement (Chandrasekaran et al. (2012); Koenig and Kleinsorge (1994)).

The relationship between service quality and patient satisfaction are two elements that are closely related. According to Donabedian (1988), patient satisfaction has emerged over the years as an essential measure of the quality of the services provided by the Health Organization. This is not only important to get insight into the perception of the customers on the health service, but is also the main results from the service.

Health service agencies face unique challenges around the world. The rising number of the hospital led to the formation of a very competitive environment because of the open-door policy in the market of medical services (Kim et al., 2008b). The growth of the elderly population and the increased focus on the health of dynamically and increase the desire as well as the specific health needs of the general public. The current medical service market more like buyers rather than sellers (Lee et al., 2010). Therefore, the field of health services is now focusing on the importance of customer-oriented marketing.

However, there are other needs in the hospital to see the satisfaction, which is necessary to develop loyalty to minimize real risks (Ranaweera and Prabhu, 2003). In developing long term relationships between hospitals and patients, not enough if only considering the quality of service (Gaur et al., 2011).

\footnotetext{
*Corresponding author. Email: octalidyaghaisani@gmail.com
} 
Patient satisfaction is closely related to patient loyalty. Kessler and Mylod (2011) and Mortazavi et al. (2009) argues that patient satisfaction is surely bound to lead to their loyalty. It is based on the assumption that if patients are satisfied with the service provided by the hospital, they are very likely to choose certain hospitals in the future and recommend the services of a hospital to another person. As a result, increase the level of loyalty among patients is the goal for all hospitals.

Here are some studies that underlie this research. Itumalla et al. (2014) study about the quality of inpatient services, using seven dimensions, namely, medical service, nursing service, supportive service, administrative service, patient safety, patient communication and hospital infrastructure. The research proved that the seven dimensions of the influential significantly to the quality of inpatient services. Similarly, research conducted by Shabbir et al. (2016) that examines perceptions of the quality of health services, satisfaction and loyalty. The result is a quality health service has a positive effect significantly to patient loyalty, to the satisfaction of the patient as mediation. Then the above opinion isreinforced by Sadeh (2017) who study about the relationship between the quality of services to the satisfaction of patients and patient loyalty. He found that service quality had a significant positive effect on patient satisfaction and patient loyalty.

By looking at the background, this research emphasizes the importance of prioritizing the quality of service, as well as observing the effect on patient satisfaction and loyalty. That is the purpose of this study, and the details are as follows. First, this study provides an integrated model that explains the relationship between service quality, patient satisfaction, and loyalty. Furthermore, the concept between these constructs is in the model. Finally, the results of this study imply new marketing for the hospital to provide a positive quality of service.

\section{Theoretical Background and Hypothesis Medical Service}

O'Connor et al. (1994) explains that medical service is the level of interaction between physicians and patients that cause communication problems and solutions of patient problems (Bitner, 1990). This involves the help, support, and hospitality of a doctor's attitude (Sardana, 2013). Medical service measures patient experience about the quality of service delivered by physicians.

Medical meetings between physicians and patients require an intensive level of interaction in which the meeting has been shown to have a significant impact on patient satisfaction O'Connor et al. (1994). This interaction usually involves complex communication patterns and customer problems (Bitner, 1990). This description leads to the following hypothesis:

\section{H1. Medical service has a positive effect on patient satisfaction.}

\section{Nursing Service}

Friendliness, courtesy, caring nurse/assistant (Otani, 2012). This is the interpersonal variable interpreted by the patient. Most of the patient surveys describe the treatment provided by the nurse or assistant and provided by the physician (Otani, 2012). Nursing Service is a major component of patient satisfaction (Kutney-Lee et al., 2009; Papastavrou et al., 2014; Qu et al., 2011). Therefore in this study, the second hypothesis is:

H2: Nursing service has a positive effect on patient satisfaction

\section{Supportive Service}

Today, there is a strong debate in defining the various types of support services provided by hospitals. Support services serve the purpose of patients, their families, and participants in a variety of ways, among them in general, this service ensures a clean, healthy, safe and secure environment in hospitals (Natarajan, 2010). However, hospital supportive services are an essential component of the treatment process, as they affect long-term recovery and quality of life (S. L. Goel and R. Kumar, 2004). Therefore in this study, the third hypothesis is:

\section{H3: Supportive service has a positive effect on patient satisfaction}




\section{Administrative Service}

Dana et al. (2016) found that administrative processes are only significant in 2012, out of three research periods on patient satisfaction (2012-2014). The administration process does not impact on patient satisfaction, or there is a gap in the patient care cycle that needs attention. However, the cause should be investigated and analyzed further.

The regression model in Dana's et al. (2016) confirmed previous research showing that patient satisfaction was strongly influenced by interpersonal factors (Koenig et al., 2009) and waiting time influenced perceptions of quality (Brady and Cronin, 2001). From some of these studies, it can be seen that administrative service, is an interesting element that still needs further clarification, whether it affects patient satisfaction or not. Therefore in this study, the fourth hypothesis is:

H4: Administrative service has a positive effect on patient satisfaction

\section{Patient Safety}

Patient safety and good quality care are regarded as the right of all patients and the responsibilities of all staff within the hospital (Zineldin et al., 2014 and Zineldin M, 2006). Meade et al (2006) conducted a study of specific nurse performance and obtained evidence that it had a significant impact on patient satisfaction. Patient safety and patient satisfaction respond equally to increased activity and nursing performance. Zineldin et al. (2011). Therefore in this study, the fifth hypothesis is:

\section{H5: Patient safety has a positive effect on patient satisfaction}

\section{Patient communication}

Patient communication is an important element, where poor communication has been frequently cited as the root of many complaints in general hospital settings (Taylor et al., 2004). Ghosh (2014) demonstrated that providing effective training to nurses, physicians and support staff on interpersonal skills and effective communication leads to inpatient satisfaction. There is growing evidence that perceived service quality is the most crucial variable affecting customer perceptions and the intention to adopt other services (Zeithaml et al., 1996). Therefore in this study, the sixth hypothesis is:

H6: Patient communication has a positive effect on patient satisfaction

\section{Hospital Infrastructure}

Patient satisfaction is to build cumulative satisfaction with various aspects of the hospital such as technical, functional, infrastructure, interaction and atmosphere (Zineldin M, 2006). Gopal et al. (2014) found results that hospital facilities (including good hospital infrastructure) and excellent service had a positive effect on patient satisfaction. Therefore in this study, the seventh hypothesis is:

\section{H7: Hospital infrastructure has a positive impact on patient satisfaction}

\section{Patient Satisfaction}

Some researchers such as Kessler and Mylod (2011) and Mortazavi et al. (2009) argue that customer satisfaction inevitably leads to their loyalty. Fisk. et al (1990) think that when customer satisfaction is high, loyalty to the hospital is also high. Therefore, customer satisfaction and loyalty to the hospital is an important index to continue the development of the hospital. Thus in this study, the eighth hypothesis is:

H8: Patient satisfaction has a positive effect on patient loyalty

\section{Patient Loyalty}

Caruana (2002) and Dabholkar et al. (1996) confirm the role of mediation of customer satisfaction on the relationship between service quality and customer loyalty. Nam et al. (2011) confirm that consumer satisfaction mediates the impact of service quality and the suitability of individual intentions to return. Lei and Jolibert (2012), argue that satisfaction and loyalty are different concepts, the most 
appropriate model used to observe the health care system is the satisfaction of mediating quality and loyalty. Therefore in this study the ninth hypothesis is:

H9: Patient satisfaction mediate the relation of service quality dimension to patient loyalty

\section{Research Methods}

\section{Data Collecting and Sampling Method}

This research using the survey method in which respondents were interviewed and asked to fill out a questionnaire or ordinal scale commonly called Likert scale as much as five points. The sampling technique used is judgment sampling. The number of samples used in this study set as many as 160 samples with the criteria of patients ever hospitalized in hospitals dr. Soehadi Prijonegoro Sragen in the last two years. The purpose of this study is hypothesis testing, namely research that explains the phenomenon in the form of relationships between variables. These variables are seven variables of inpatient service quality, patient satisfaction and patient loyalty.

\section{Variable definitions}

Service quality is the measurement of customer assessment on how far the difference between the real service and their expectations. Parasuraman et al., (1998) proposed an instrument to measure customer perceptions of service quality known as SERVQUAL (reliability, responsiveness, assurance, empathy, and tangible). The indicators of service quality in this study are adapted from Itumalla et al., (2014), researching about the quality of inpatient services, using seven dimensions, namely, medical service, nursing service, supportive service, administrative service, patient safety, patient communication and hospital infrastructure. Medical service is measured using the speed of service, pay attention to complaints, visiting time and giving information. Nursing service: speed of service, offering medicine, courtesy, providing assistance. Supportive service: speed of diagnosis, the availability of drugs, food quality, and environmental hygiene. Administrative service: administration process, supporting facilities, problem-solving and check out process. Patient safety: hygiene process, patient safety, and no infection. Patient communication: giving information, clarity of information, and family discussion. Hospital infrastructure: physical facilities, the sophistication of equipment and staff appearance.

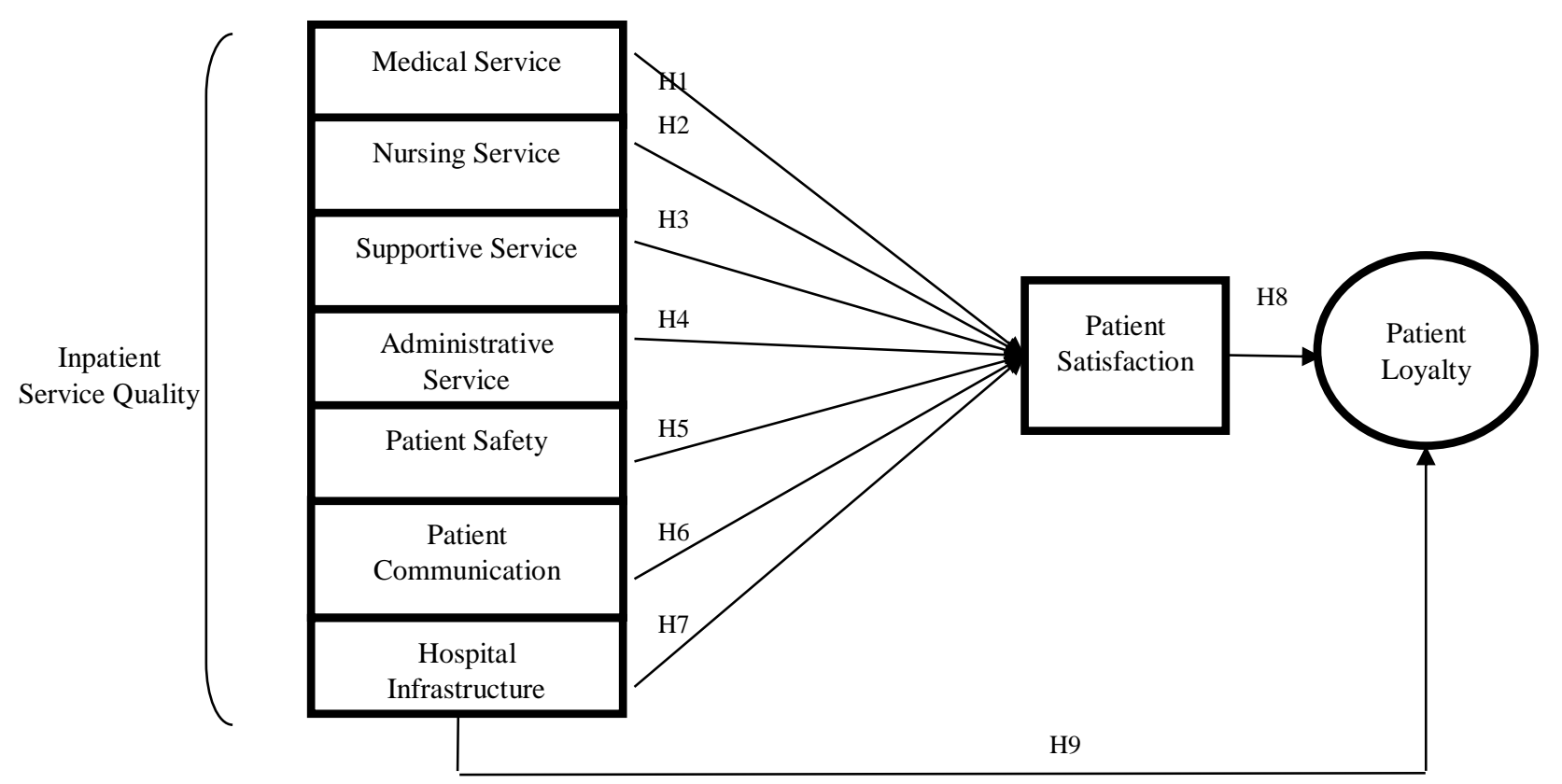

Figure 1. The model of Patient Loyalty 
Customers' satisfaction is well-defined as comparing the perceived performance with the expectations and then meeting those expectations. Customers are said to be satisfied if perceived performance is greater than expectations while if it does not, then the customers are said to be dissatisfied (Oliver, 1997; Zeithaml, V.A. and Bitner, 2000). Because in developing long term relationships between hospitals and patients, service quality is not only sufficient to be considered (Gaur et al., 2011), so there is a need for hospitals to look elsewhere satisfaction to develop loyalty to minimize the apparent risks (Ranaweera and Prabhu, 2003). The indicators of patient satisfaction and patient loyalty in this study are adapted from Sadeh and Garkaz (2015) researching about patient satisfaction using four items, satisfaction with physical facilities, satisfaction with staff performance, satisfaction with technical and medical services, and satisfaction with cost. Patient loyalty using three elements: positive word-of-mouth, recommending to others, and willingness to reuse.

\section{Result and Discussion}

Based on the research that has been done, then we present the following description of 160 respondents in Table 1.

Table 1. Respondents' profile

\begin{tabular}{|c|c|c|c|}
\hline Description & Category & Frequency & Percentage \\
\hline \multirow{5}{*}{ Age (years) } & $<18$ & 1 & $0,6 \%$ \\
\hline & $19-30$ & 3 & $1,9 \%$ \\
\hline & $31-50$ & 14 & $30,0 \%$ \\
\hline & $51-70$ & 84 & $52,5 \%$ \\
\hline & $>70$ & 24 & $15 \%$ \\
\hline \multirow{2}{*}{ Gender } & Female & 82 & $51,2 \%$ \\
\hline & Male & 78 & $48,8 \%$ \\
\hline \multirow{7}{*}{ Employment } & Government employees & 15 & $9,4 \%$ \\
\hline & Entrepreneur & 30 & $18,8 \%$ \\
\hline & Private Employees & 3 & $1,9 \%$ \\
\hline & Student & 1 & $0,6 \%$ \\
\hline & Others & 111 & $69,4 \%$ \\
\hline & $<\operatorname{Rp} 1.500 .000$ & 109 & $68,1 \%$ \\
\hline & Rp1.500.000-Rp 2.000.000 & 22 & $13,8 \%$ \\
\hline \multirow[t]{3}{*}{ Income } & $\begin{array}{c}\mathrm{Rp} 2.000 .001-\mathrm{Rp} \\
3.000,000\end{array}$ & 8 & $5 \%$ \\
\hline & $>$ Rp 3.000.000 & 21 & $13,8 \%$ \\
\hline & No School & 36 & $22,5 \%$ \\
\hline \multirow{4}{*}{ Education } & Primary School & 59 & $36,9 \%$ \\
\hline & Junior high School & 31 & $19,4 \%$ \\
\hline & Senior high School & 20 & $12,5 \%$ \\
\hline & College/Academy & 14 & $8,8 \%$ \\
\hline
\end{tabular}

\section{Test Instruments}

Validity test of this research using confirmatory factor analysis (CFA) with SPSS. This study uses a guidance factor loading 0.5. From the validity test, obtained KMO of Sampling Adequacy (KSOMSA) test of 0.956, i.e.> 0.5050 so that factor analysis can be done. Validity test results Confirmatory factor analysis (CFA) in this study show the entire item question meets the criteria. Reliability test results of this study are almost entirely has a Cronbach's Alpha value between $0.8-1.0$. Thus the ten variables used in research reliability is good. Results can be seen in Table 2. 
Table 2. Validity and Reliability Test

\begin{tabular}{llllll}
\hline Variable & Loading & $\begin{array}{c}\text { Cronbach' } \\
\text { s Alpha }\end{array}$ & Variable & Loading & $\begin{array}{c}\text { Cronbach's } \\
\text { Alpha }\end{array}$ \\
\hline X.1 & 0.948 & & X.17 & 0.966 & \\
X.2 & 0.919 & & X.18 & 0.969 & 0.971 \\
X.3 & 0.923 & 0.968 & X.19 & 0.952 & \\
X.4 & 0.917 & & X.20 & 0.945 & \\
X.5 & 0.924 & & X.21 & 0.950 & 0.958 \\
X.6 & 0.844 & & X.22 & 0.928 & \\
X.7 & 0.893 & 0.939 & X.23 & 0.968 & \\
X.8 & 0.930 & & X.24 & 0.967 & 0.943 \\
X.9 & 0.889 & & X.25 & 0.866 & \\
X.10 & 0.891 & & M.1 & 0.919 & \\
X.11 & 0.962 & 0.953 & M.2 & 0.927 & \\
X.12 & 0.949 & & M.3 & 0.930 & 0.970 \\
X.13 & 0.957 & & M.4 & 0.845 & \\
X.14 & 0.971 & & Y.1 & 0.951 & \\
X.15 & 0.936 & 0.970 & Y.2 & 0.966 & \\
X.16 & 0.927 & & & 0.960 & \\
\hline
\end{tabular}

\section{Descriptive Statistics}

From the results of descriptive statistic, get results all the correlation between positive variable significant. In addition, the correlation between independent variables is less than 0.80 so it can be concluded the absence of multicollinearity problems.

Table 3. Desriptive Statistics and correlation matrix

\begin{tabular}{|c|c|c|c|c|c|c|c|c|c|c|c|}
\hline Variable & Avg. & $\mathrm{SD}$ & MS & NS & SS & AS & PS & $\mathrm{PC}$ & $\mathrm{HI}$ & PS & PL \\
\hline Medical Service (MS) & 3.69 & 0.97 & 1 & & & & & & & & \\
\hline Nursing Service (NS) & 3.78 & 0.84 & 0.47 & 1 & & & & & & & \\
\hline Supportive Service (SS) & 3.69 & 0.88 & 0.39 & 0.65 & 1 & & & & & & \\
\hline Administrative Service (AS) & 3.77 & 0.82 & 0.37 & 0.67 & 0.58 & 1 & & & & & \\
\hline Patient Safety (PS) & 3.71 & 0.81 & 0.36 & 0.59 & 0.56 & 0.46 & 1 & & & & \\
\hline Patient Communication (PC) & 3.79 & 0.79 & 0.38 & 0.43 & 0.48 & 0.42 & 0.57 & 1 & & & \\
\hline Hospital Infrastructure (HI) & 3.84 & 0.86 & 0.43 & 0.40 & 0.27 & 0.31 & 0.54 & 0.47 & 1 & & \\
\hline Patient Satisfaction (PS) & 3.80 & 0.83 & 0.50 & 0.57 & 0.57 & 0.44 & 0.47 & 0.58 & 0.56 & 1 & \\
\hline Patient Loyalty (PL) & 3.79 & 0.76 & 0.68 & 0.55 & 0.36 & 0.47 & 0.49 & 0.47 & 0.52 & 0.48 & 1 \\
\hline
\end{tabular}

\section{Classical assumption test}

\section{- Normality Test:}

Normality test is done to determine whether the residuals in the regression model normal distribution method used is Kolmogorov-Smirnov, residual considered normal for a sig KolmogorovSmirnov >0.05, normality test results are shown in Table 4. 
Table 4. Normality Test Results

\begin{tabular}{lcc}
\hline Variable & Sig Kolmogorov-Smirnov & Information \\
\hline Residual & 1.304 & Normal \\
\hline
\end{tabular}

- Heteroscedasticity Test:

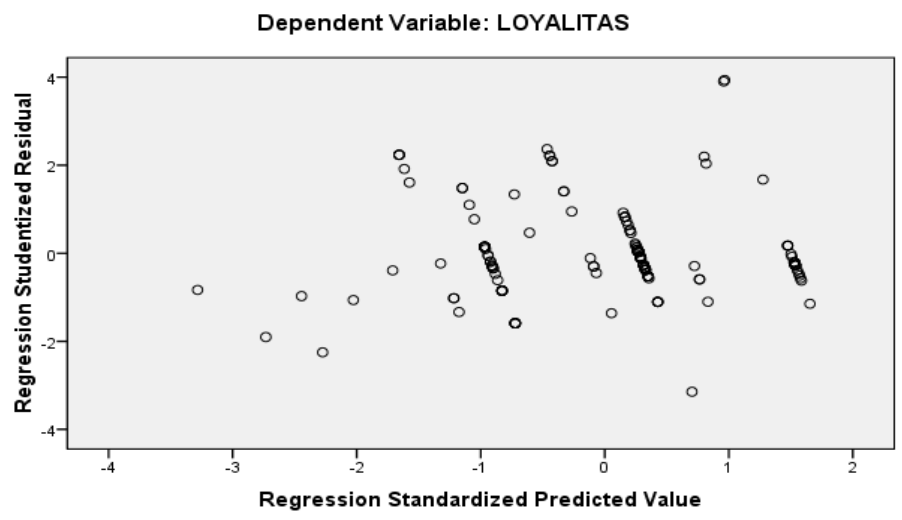

Figure 2. Scatterplot

Results scatter plot appears in Figure 2 plots the results obtained indicate that there are dots spread randomly and do not form a pattern (there was no trouble heteroscedasticity).

\section{Hypothesis Testing}

After the instrument test, then the next stage is the hypothesis test analysis. Here are the results of hypothesis testing in this study:

Table 5. Hypothesis Test Results

\begin{tabular}{cccccc}
\hline $\begin{array}{c}\text { Influence between } \\
\text { variables }\end{array}$ & Beta & Sig. Test t & Sig. Test F & adj R ${ }^{2}$ & Results \\
\hline MS $\rightarrow$ PS & 0.546 & 0.000 & 0.000 & 0.764 & H1 accepted \\
NS $\rightarrow$ PS & 0.655 & 0.000 & 0.000 & 0.805 & H2 accepted \\
SS $\rightarrow$ PS & 0.697 & 0.000 & 0.000 & 0.793 & H3 accepted \\
AS $\rightarrow$ PS & 0.698 & 0.000 & 0.000 & 0.874 & H4 accepted \\
PS $^{1} \rightarrow$ PS $^{2}$ & 0.918 & 0.000 & 0.000 & 0.832 & H5 accepted \\
PC $\rightarrow$ PS & 1.039 & 0.018 & 0.000 & 0.816 & H6 accepted \\
HI $\rightarrow$ PS & 0.953 & 0.000 & 0.000 & 0.910 & H7 accepted \\
PS $\rightarrow$ PL & 0.916 & 0.000 & 0.000 & 0,864 & H8 accepted \\
7-dimensions & The significance value of the test f and beta & H9 accepted, \\
Service Quality & results are positively significant on the overall & PS as partial \\
$\rightarrow$ PS $\rightarrow$ PL & relationship between variables & & mediation \\
\hline
\end{tabular}

Notes: MS = Medical Service; $\mathrm{PC}=$ Patient Communication; NS = Nursing Service $; \mathrm{HI}=$ Hospital Infrastructure; SS = Supportive Service; PS2 = Patient Satisfaction; AS = Administrative Service; PL = Patient Loyalty 


\section{Conclusion}

From the results obtained in this study, we could draw three conclusions. First, inpatient service quality (medical service, nursing service, supportive service, patient safety, patient communication, and hospital infrastructure) positively impact patient satisfaction. It can be used as a strategy for the management to improving inpatient service quality, so patients can be satisfied with the services they provide. Second, patient satisfaction have significant positive effect on patient loyalty, suggesting that patient satisfaction is extremely influential on patient loyalty. By improving the quality of services, it is expected that the patients were satisfied, and then loyal after satisfied with inpatient service quality in the hospital. Third, patient satisfaction could have a role as partial mediating variables proved significant positive effect on patient loyalty, although loyalty can arise without going through patient satisfaction, but it can been able to show that someone is going to use inpatient service in this hospital again if they are satisfied with the services provided at this hospital.

\section{References}

Bitner, M.J. (1990), "Evaluating Service Encounters: The Effects of Physical Surroundings and Employee Responses", Journal of Marketing, Vol. 54 No. 2, p. 69.

Brady, M.K. and Cronin, J. (2001), "Some new thoughts on conceptualizing perceived service quality: a hierarchical approach", Journal of Marketing, Vol. 65, pp. 34-49.

Caruana, A. (2002), "Service loyalty: The effects of service quality and the mediating role of customer satisfaction", European Journal of Marketing, Vol. 36 No. 7/8, pp. 811-828.

Chandrasekaran, A., Senot, C. and Boyer, K.K. (2012), "Process Management Impact on Clinical and Experiential Quality: Managing Tensions Between Safe and Patient-Centered Healthcare”, Manufacturing E Service Operations Management, Vol. 14 No. 4, pp. 548-566.

Dabholkar, P.A., Thorpe, D.I. and Rentz, J.O. (1996), “A Measure of Service Quality for Retail Stores”, Journal of the Academy of Marketing Science, Vol. 24 No. Winter, pp. 3-16.

Dana, M. J., Roberta, S. R., Sheneeta, W. W. (2016), "Perceptions of care quality and the effect on patient satisfaction", International Journal of Quality \& Reliability Management, Vol. 33 No. 8, pp. 1202 - 1229.

Fisk, Trevor A.,Brown, Carmheil J., Cannizzaro, Kathleen, Naftal, B. (1990), "Creating Patient Satisfaction and Loyalty", Journal of Health Care Marketing, Vol. 10 No. 2, pp. 5-15.

Gaur, S.S., Xu, Y., Quazi, A. and Nandi, S. (2011), "Relational impact of service providers' interaction behavior in healthcare", Managing Service Quality, Vol. 21 No. 1, pp. 67-87.

Ghosh, M. (2014), "Measuring patient satisfaction: An empirical study in India”, Leadership in Health Services, Vol. 27 No. 3, pp. 240-254.

Gopal, R., Satvinder, \& and Bedi, S. (2014), "Impact of Hospital Services on Outpatient Satisfaction”, International Journal of Research in Business Management, Vol. 2 No. 4, pp. 2321-886.

Itumalla, R., Acharyulu, G.V.R.. and Shekhar, B.R. (2014), "Development of HospitalQual: A Service Quality Scale for Measuring In-patient Services in Hospital”, Operations and Supply Chain Management: An International Journal, Vol. 7 No. 2, p. 54.

Kessler, D.P. and Mylod, D. (2011), "Does patient satisfaction affect patient loyalty?”, International Journal of Health Care Quality Assurance, Vol. 24 No. 4, pp. 266-273.

Kim, Y.K., Cho, C.H., Ahn, S.K., Goh, I.H. and Kim, H.J. (2008), "A study on medical services quality and its influence upon value of care and patient satisfaction - Focusing upon outpatients in a large-sized hospital”, Total Quality Management and Business Excellence, Vol. 19 No. 11, pp. 1155-1171.

Koenig, H.F., and Kleinsorge, I. K. (1994), "Perceptual measures of quality: a tool to improve nursing home systems", Hospital \& Health Service Administration, Vol. 39, pp. 487-503.

Kutney-Lee, A., McHugh, M.D., Sloane, D.M., Cimiotti, J.P., Flynn, L., Neff, D.F. and Aiken, L.H. (20o9), "Nursing: A key to patient satisfaction", Health Affairs, Vol. 28 No. 4, pp. 669-677.

Lee, W.I., Chen, CW, Chen TH, C.C. (2010), "The relationship between consumer orientation, service value, medical care service quality and patient satisfaction: The case of a medical center in Southern Taiwan, Afr, J, Bus, Manage", Vol. 4, pp. 448-458.

Lei, P. and Jolibert, A. (2012), "A three-model comparison of the relationship between quality, satisfaction and loyalty_2012”, BMC Health Services Research, Vol. 12, p. 436.

Meade M and Bursell, K. (2006), "ing rounds: on patients' call light use, satisfaction, and safety", American Journal of Nursing, Vol. 106, pp. 58-70.

Mortazavi, S., Kazemin, M., Shirazi, A. and Aziz-Abadi, A. (2009), “The relationships between patient satisfaction and loyalty in the private hospital industry", Iranian Journal of Public Health, Vol. 38, pp. 6o-69.

Nam, J., Ekinci, Y. and Whyatt, G. (2011), "Brand equity, brand loyalty and consumer satisfaction”, Annals of Tourism Research, Elsevier Ltd, Vol. 38 No. 3, pp. 1009-1030.

Natarajan, S. (2010), Hospital Supportive Services, Excel Books, New Delhi. 
O'Connor, S,J,, Shewchuk, S,R, and Bowers, M. (1994), "A model of service quality perceptions and health care consumer behavior", Journal of Hospital Marketing, Vol. 6, pp. 69-92.

Oliver, R. (1997), Satisfaction: A Behavioural Perspective on the Consumer, McGraw Hill, New York.

Otani, K., Waterman, B. and Dunagan, W.C. (2012), "Journal of Healthcare Management", Patient Satisfaction: How Patient Health Conditions Influence Their Satisfaction, Vol. 57, pp. 276-293.

Papastavrou, E., Andreou, P., Tsangari, H. and Merkouris, A. (2014), "Linking patient satisfaction with nursing care: The case of care rationing - a correlational study”, BMC Nursing, Vol. 13 No. 1, pp. 1-10.

Parasuraman, V. and Zeithaml, A. (1998), "SERVQUAL: A Multiple-Item Scale for Measuring Consumer Perceptions of Service Quality”, Journal of Retailing, Vol. 64, pp. 12-37.

Qu, H., Platonova, E.A., Kennedy, K.N. and Shewchuk, R.M. (2011), "Primary care patient satisfaction segmentation", International Journal of Health Care Quality Assurance, Vol. 24 No. 7, pp. 564-576.

Ranaweera, C. and Prabhu, J. (2003), "The influence of satisfaction, trust and switching barriers on customer retention in a continuous purchasing setting”, International Journal of Service Industry Management, Vol. 14 No. 4, pp. 374-395.

S. L. Goel and R. Kumar. (2004), Hospital Supportive Services, Deep \& Deep Publications, New Delhi.

Sadeh, E. (2017), "Interrelationships among quality enablers, service quality, patients' satisfaction and loyalty in hospitals”, TQM Journal, Vol. 29 No. 1, pp. 101-117.

Sadeh, E. and Garkaz, M. (2015), "Explaining the mediating role of service quality between quality management enablers and students' satisfaction in higher education institutes: the perception of managers", Total Quality Management and Business Excellence, Vol. 26 No. 11-12, pp. 1335-1356.

Sánchez-Hernández, R.M., Martínez-Tur, V., Peiró, J.M. and Ramos, J. (2009), "Testing a hierarchical and integrated model of quality in the service sector: Functional, relational, and tangible dimensions", Total Quality Management and Business Excellence, Vol. 20 No. 11, pp. 1173-1188.

Sardana, G.. (200o). "Performance grading of hospitals: a conceptual framework", Productivity, Vol. 44, pp. 450-465.

Shabbir, A., and Malik, S.A. (2016), "Measuring patients' healthcare service quality perceptions, satisfaction, and loyalty in public and private sector hospitals in Pakistan\&quot;Hospital service quality and its effects on patient satisfaction and behavioural intention\&quot; Clinical Govern”, International Journal of Quality E Reliability Management International Journal of Pharmaceutical and Healthcare Marketing Iss- International Journal Iss, Vol. 33 No. 5, pp. 538-557.

Taylor, D.M., Wolfe, R.S. and Cameron, P.. (2004), "Analysis of complaints lodged by patients attending Victorian hospitals, 1997-2001”, Medical Journal of Australia, Vol. 6o, pp. 31-46.

Zeithaml, V., Berry, L. and Parasuraman, A. (1996), “The behavioral consequences of service quality”, Journal of Marketing, Vol. 6o, pp. 31-46.

Zeithaml, V.A. and Bitner, M.J. (2000), Services Marketing: Integrating Customer Focus Across the Firm, McGrawHill, New York.

Zineldin, M., Zineldin, J., \& Vasicheva, V. (2014), “Approaches for reducing medical errors and increasing patient safety:TRM, quality and 5 Qs method”, The TQM Journal, Vol. 26, pp. 63-74.

Zineldin, M., Camgöz-Akdağ, H. and Vasicheva, V. (2011), "Measuring, evaluating and improving hospital quality parameters/dimensions - An integrated healthcare quality approach", International Journal of Health Care Quality Assurance, Vol. 24 No. 8, pp. 654-662.

Zineldin M. (2006), "The quality of healthcare and patient satisfaction: an exploratory investigation of the 5Qs model at some Egyptian and Jordanian medical clinics", International Journal of Healthcare Quality Assurance, Vol. 19, pp. 60-92. 